\title{
ウワバミソウの挿し穂の発根と生育に及ぼす水挿し時の培養液濃度の影響
}

\author{
水島智史 * \\ 福井県立若狭東高等学校 917-0293 福井県小浜市金屋
}

\section{Effects of Nutrient Solution Concentration on Rooting and Growth of Cuttings in Elatostema involucratum Franch. \& Sav. Cultured by Hydroponics}

\author{
Satoshi Mizushima* \\ Fukui Prefectural Wakasa East High School, Obama, Fukui 917-0293
}

\begin{abstract}
The effects of the nutrient solution concentration on the rooting and growth of cuttings in Elatostema involucratum Franch. $\&$ Sav. cultured by hydroponics were investigated. The rooting rate of cuttings cultured at nutrient solution concentration of 0.1 and 0.25 units $\left(0.5\right.$ and $0.8 \mathrm{dS} \cdot \mathrm{m}^{-1}$, respectively.) was equal to or more than that of cuttings cultured at 0 units. The rooted cuttings cultured at a concentration of 0.1 units showed faster growth during the nursery period and after transplantation than that of cuttings cultured at 0 units. The root growth of rooted cuttings cultured at 0.25 units was inhibited in the nursery period. In the nursery period, the relative growth rate (RGR) of rooted cuttings cultured at 0.1 units was higher than that of cuttings cultured at 0 units. The change in RGR was related to the net assimilation rate.
\end{abstract}

Key Words : cutting, growth analysis, hydroponics, vegetative propagation

キーワード：栄養繁殖，挿し芽，成長解析，水耕

\section{緒言}

ウワバミソウ (Elatostema involucratum Franch. \& Sav.) は, 山中の陰湿な斜面や崖に群をなして生ずるイラクサ科の多 年生草本植物であり，ミズナ，ミズ，クチナワショョウゴと も呼ばれる (牧野, 1940)。本種は, 山菜として利用され て扣り, 栽培化も進められつつあり, 土耕だけでなく水耕 での栽培の実用化が期待される (大沢, 1986). 水島 (2015a) は, 珠芽を用いてウワバミソウを水耕し, 園試処方第 2 例 の修正処方 0.25 単位 $\left(\mathrm{EC}\right.$ 約 $0.8 \mathrm{dS} \cdot \mathrm{m}^{-1}$ ) 以下の培養液 濃度が生育に適すると報告した。 また，水島（2015b）は， ウワバミソウの挿し穂を鹿沼土に挿して育苗した後に水耕 したところ, 前述の処方および濃度の培養液で生育が優れ たと報告した.

白井・萩森（2004）は，ピーマンの挿し芽繁殖を前提と して挿し穂採取用の母株を養液栽培と土耕で栽培した結 果, 挿し穂収量は養液栽培で多かったと報告した。谷川ら （2010）は，キクの親株を針葉樹の樹皮を培地に用いて養 液栽培したところ, 土耕と比較して挿し穂収量が多かった と報告した. このよらに, 挿し穂の確保といら観点から土 耕と比較して養液栽培での優位性が示されている. ウワバ

2015 年 10 月 21 日 受付. 2016 年 3 月 14 日 受理.

* Corresponding author. E-mail: s-mizushima-f5@ma.fukui-ed.jp
ミソウの主な繁殖方法は，挿し芽，珠芽の利用など栄養繁 殖である，従って，ウワバミソウの水耕に関する技術を整 備することは，利用部位である茎葉の収穫だけでなく，挿 し芽で繁殖されるウワバミソウの効率的な増殖にもつなが ると考えられる.

挿し芽では，挿し穂をバーミキュライトや鹿沼土，ロッ クウールなどの培地に挿すことが多い。しかしながら，育 苗後に水耕する場合，插し芽苗の根部に付着した培地を取 り除かなければならないため, 培地を除去するための労力 が発生し，根部の傷みも生じやすいと考えられる。並木ら （1977）はトマトに拈いて水插しによる挿し芽苗の育成方 法を報告し，水耕で育苗する利点として移植の際に根に付 着した土や砂を洗い落とす必要がない，鉢上げが簡単にな る，培養液中で発根できるので生育の遅れが少ないなどを あげた。

一般的に，挿し床は肥料を含まない方が良いとされてい る。しかしながら, 岩腰ら（2003）は，人工光型湛液育苗 装置を利用して大玉トマトの挿し穂を水, または大塚 A 処方培養液 $0.1,0.5$ 打よび 1 単位培養液に挿したところ, 0.5 単位以上では根の伸長抑制や插し穂の腐敗が認められた が, 0.1 単位では根の生育が優れたと報告した。畑ら (2009) は, レンギョウの当年枝を挿し穂としてロックウール キューブに挿し，水道水，大塚 $\mathrm{A}$ 処方 0.1 および 1 単位培 養液を 1 日に 1 回与えたところ, 根の生育は水道水と比較 
して 1 単位培養液では阻害されたが, 0.1 単位培養液では 促進される傾向であったと報告した．西尾ら（1994）は, キクを窒素施肥量 $0 \sim 90 \mathrm{mg} ・ \mathrm{~L}^{-1}$ とした培地を詰めたセル トレイに挿し芽したところ，根の生育は $60 \mathrm{mg}$ で優れたと 報告した。 このように, 低濃度培養液あるいは低窒素濃度 が挿し穂の根の生育を促進することが示されている。 しか しながら，挿し穂の発根に及ぼす影響は不明である。

そこで本研究では, 水耕を前提として, ウワバミソウを 水扦して培養液濃度と挿し穂の発根拈よび生育の関係を 調査した.

\section{材料および方法}

\section{1. 水挿し時の培養液濃度がウワバミソウの挿し穂の発根 と生育に及ぼす影響（実験 1）}

福井県立若狭東高等学校の閉鎖型培養室（気温 $22^{\circ} \mathrm{C}$, 相対湿度 65～70\%）で試験を実施し，全期間観賞魚用工 アーポンプで培養液に連続通気した，培養液の処方および 調製方法は水島（2015a）の方法に準じた.

2014 年 5 月 17 日に福井県大飯郡扣扎い町の自生地で天 挿し用の扦し穂を採取し, 茎長約 $5 \mathrm{~cm}$, 葉数 $2 \sim 3$ 枚に調 製した。扦し穂の基部は約 45 度の角度に, 長い葉は葉身 を約 $3 \mathrm{~cm}$ 残して切断した. 挿し穂を 1 時間吸水させた後, プラスチックコンテナ（内寸：縦 $37.0 \mathrm{~cm}$, 横 $25.5 \mathrm{~cm}$, 高

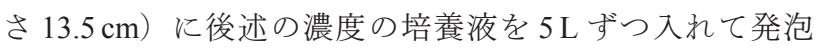
ポリエチレンシートを浮かべ, $2.5 \mathrm{~cm}$ 間隔で挿し穂を挿し た。培養液濃度は $0,0.1$ および 0.25 単位の 3 段階とし， 1 試験区当たり 33 本の挿し穂を供した。挿し芽後，コンテ ナ上部を食品用包装フィルムで覆い, 挿し芽 10 日後に除 去した. 照明には白色蛍光灯（FL40S・W，東芝ライテッ ク（株）を用い，16 時間日長とした。照度計（SPI-71, 東 京光学機械 (株)）で測定した発泡ポリエチレンシート表 面での照度は，插し芽当日〜10 日後までは插し穗の萎调 を抑えるために約 100 lx とし，挿し芽 10 日後〜実験終了 までは約 3,000 1x とした。育苗期間中に培養液の交換は 行わず，減少分は水道水を補給した。 な拈，本研究では挿 し芽〜定植までの期間を育苗と定義した。

挿し芽 28 日後の 6 月 14 日に発根した挿し穂（挿し芽 苗）の最下位葉の直下の茥をウレタンキューブで挟み込 久, 培養液面に浮かべた発泡ポリエチレンシートに株間 $10 \mathrm{~cm}$, 条間 $5 \mathrm{~cm}$ で苗を差し込み, 1 コンテナ当たり 9 株 ずつ, 各区 18 株ずつ定植した。育苗期間中の培養液濃度 に関わらず，定植時の培養液濃度は 0.25 単位で統一した。 定植後の培養液量は 1 コンテナ当たり $3 \mathrm{~L}$ として栽培中の 減少分は水道水を補給し，10日ごとに培養液を全量交換 した。

挿し芽後, 発根した挿し穂の数を 1 日に 1 回調査して発 根率を算出した。な括，挿し穂から不定根を目視できた段 階を発根と定義した，定植当日に最大根長を，定植当日か ら 7 日ごとに主茥長执よび節数を調査した。定植当日拈よ
び45 日後にそれぞれ 10 株および 18 株の茎葉および根の 新鮮重を測定した．茥葉の測定ではウレタンキューブより 上の茎葉，根の測定では不定根を調査対象とした．定植当 日の 10 株および定植 45 日後の茎葉と根の合計新鮮重が中 庸な 10 株を用い，各株の合計新鮮重を基に並べ替えて同 一順位となった株を同一個体とみなして新鮮重を基にした 相対成長率 (RGR) を算出し, 統計処理した.

\section{2. 異なる培養液濃度で水扦ししたウワバミソウの挿し芽 苗の成長解析 (実験 2)}

2013 年 10 月 20 日に実験 1 と同じ自生地で珠芽を採取 して，湿らせたバーミキュライトと混合してビニール袋に 入れて $4{ }^{\circ} \mathrm{C} て ゙$ 保管した. 2014 年 8 月 18 日に珠芽を取り出 し，0.25 単位の培養液で水耕して挿し穂採取用の母株を育 成した。

2015 年 1 月 13 日に母株から天挿し用の挿し穂を採取し た. プラスチックコンテナに 0 拈よび 0.1 単位の培養液を

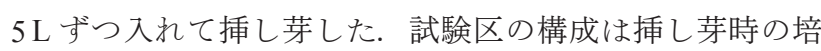
養液濃度を 0 执よび 0.1 単位として育苗終了まで同じ培養 液で管理する 0 扎よび 0.1 単位と，挿し芽時の培養液濃度 を 0 単位として挿し芽 14 日後に培養液濃度を 0.1 単位に 変更して管理する $0 / 0.1$ 単位の 3 区とし， 1 試験区当たり 33 本の插し穂を供した。 $0 / 0.1$ 単位区の挿し芽 14 日後を 除いて, 育苗期間中に培養液の交換は行わず減少分は水道 水を補給した．挿し芽後，コンテナ上部を食品用包装フィ ルムで覆い, 挿し芽 15 日後に除去した。発泡ポリエチレ ンシート表面での照度は，挿し芽当日〜7日後までは約 $1001 \mathrm{x}$ ，挿し芽 7 日後〜実験終了まで約 $3,0001 \mathrm{x}$ とした。

挿し芽 25 日後の 2 月 7 日に挿し芽苗を株間 $5 \mathrm{~cm}$, 条間 $5 \mathrm{~cm}$ で，1 コンテナ当たり 18 株ずつ，各区 18 株ずつ定植 した。育苗期間中の培養液濃度にかかわらず，定植時の培 養液濃度は 0.25 単位で統一し, 培養液量は 1 コンテナ当 たり $5 \mathrm{~L}$ とした，栽培中の培養液の減少分は水道水を補給 し，定植 10 日後に培養液を全量交換した。 その他の試験 条件は実験 1 と同様とした。

挿し芽後, 発根した挿し穂の数を 1 日に 1 回調査して発 根率を算出した。な拈，0０.1 単位区の発根率は，発根率 の調査期間中の培養液濃度が 0 単位であるため， 0 単位区 と統合した、葉，茥执よび根の乾物重，葉面積，葉数拈よ び最大根長を挿し芽当日，定植時，定植 7 および 14 日後 に各区 8 株ずつ調査した。葉および根の乾物重測定ではそ れぞれ着生している葉および不定根を調査対象とした。茥 の乾物重測定では地上部だけでなくウレタンキューブより 下の不定根を除去した部分を含めて調査対象とした。乾物 重は, 乾燥器（MOV-202，三洋電機（株））を使用して $85^{\circ} \mathrm{C}$ で 48 時間乾燥させた後に測定した。葉身を一定面積 のスケールとともに複写後, 複写された葉身とスケール部 分を切り抜き，それぞれの紙の重さの比から算出した葉面 積と葉身長と幅の積の間には第 1 図に示すよらな高い正の 相関（r=0.977）が認められた。第 1 図の回帰式に葉身長 


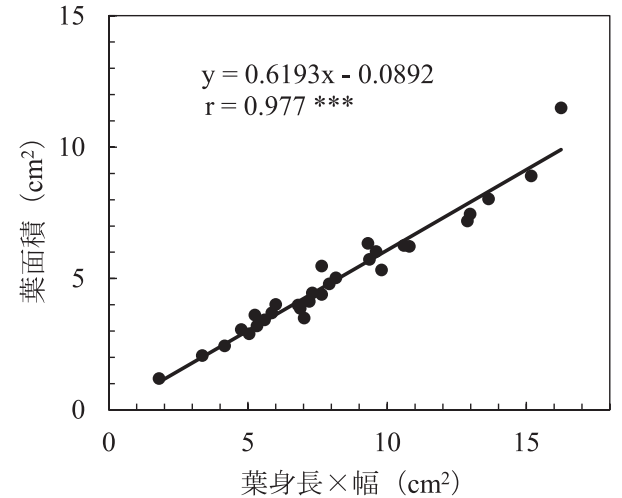

第 1 図 ウワバミソウに抢ける葉面積と葉身長と幅の積の相関 ***は $0.1 \%$ 水準で有意なことを示す $(\mathrm{n}=30)$

と幅の積を代入して得た值を葉面積とした．全乾物重と葉 面積を基にして, 劉ら（2008）の計算式で相対成長率 (RGR)，葉面積比（LAR）および純同化率（NAR）を算 出した。育苗中和よび定植 $0 \sim 14$ 日後の各期間中の葉, 茎打よび根の乾物増加量を基に乾物分配率を算出した。な 抒, 挿し芽当日, 定植当日抒よび 14 日後の各株の全乾物 重を基に並べ替えて同一順位となった株を同一個体とみな して，RGR，LAR，NAR 抒よび乾物分配率を算出し，統 計処理した.

\section{結果}

\section{1. 水挿し時の培養液濃度がウワバミソウの挿し穂の発根 と生育に及ぼす影響（実験 1）}

すべての培養液濃度に打いて, 発根率の推移はほぼ同じ であり, 捜し芽 7 日後に挿し穂の発根が始まり, 指し芽 9 日後に発根率は $100 \%$ に達した（第 2 図）。

定植当日拈よび定植 45 日後の茎葉新鮮重は，0 単位と 比較して 0.1 打よび 0.25 単位で有意に重かった（第 1 表）. 定植当日の根新鮮重は， 0 および 0.1 単位では両区間には 有意な差は認められなかったが, 0.25 単位では 0 和よび 0.1 単位と比較して有意に軽かった。定植 45 日後の根新鮮重 は， 0 単位と比較して 0.1 拈よび 0.25 単位で有意に重かっ た. 定植 $0 \sim 45$ 日後の RGR は， 0 単位と比較して 0.1 お よび 0.25 単位で有意に高かった.

主茎長は，定植 $0 \sim 42$ 日後のすべての調査日において 0

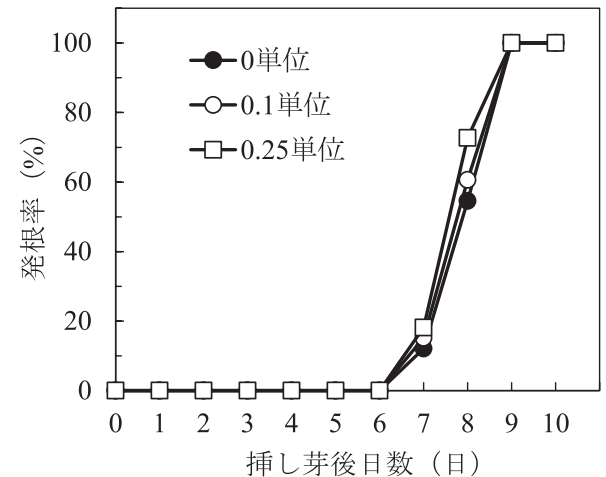

第 2 図 ウワバミソウの搟し穂の発根率に及ぼす水挿し時の 培養液濃度の影響（実験 1)

単位と比較して 0.1 预よび 0.25 単位で有意に長かった（第 3 図 A).

節数は, 定植 $0 \sim 14$ 日後の期間では各区に有意な差は 認められなかったが，0 単位と比較して 0.1 単位では定植 21 日後以降, 0.25 単位では定植 42 日後で有意に多くなっ た(第 3 図 B ).

\section{2. 異なる培養液濃度で水括ししたウワバミソウの挿し芽 苗の成長解析 (実験 2)}

0 打よび 0.1 単位の培養液濃度に扮いて, 発根率の推移 はほぼ同じであり，插し芽 3 日後に挿し穂からの発根が始 まり, 挿し芽 8 日後に発根率は $100 \%$ に達した（第 4 図）。

定植当日（挿し芽 25 日後）の葉乾物重は，0 単位と比 較して，0/0.1 抢よび 0.1 単位で有意に重かった（第 5 図 A)。定植 7 抢よび 14 日後（それぞれ挿し芽 32 拈よび 39 日後）の葉乾物重は， 0 単位と比較して $0 / 0.1$ 単位では 有意な差は認められなかったが，0.1 単位では有意に重 かった.

定植当日の茎乾物重は， 0 単位と比較して，0/0.1 単位 では有意な差は認められなかったが， 0.1 単位では有意に 重かった（第 5 図B）。定植 7 打よび 14 日後の茎乾物重 は, 0 拈よび $0 / 0.1$ 単位と比較して 0.1 単位で有意に重かっ た.

根乾物重は，定植当日抢よび定植 7 日後ではいずれの試 験区間に扔いても有意な差は認められなかったが，定植 14 日後では 0 単位と比較して 0.1 単位で有意に重かった

第 1 表 水挿し時の培養液濃度がウワバミソウの挿し芽苗の定植後の茎葉新鮮重および根新鮮 重ならびにRGRに及ぼす影響

\begin{tabular}{|c|c|c|c|c|c|}
\hline \multirow{2}{*}{ 培養液濃度 } & \multicolumn{2}{|c|}{ 茎葉新鮮重（mg／株） } & \multicolumn{2}{|c|}{ 根新鮮重（mg／株） } & \multirow{2}{*}{$\frac{\mathrm{RGR}^{\mathrm{z}}}{\left(\mathrm{day}^{-1}\right)}$} \\
\hline & 定植当日 & 定植 45 日後 & 定植当日 & 定植 45 日後 & \\
\hline 0 単位 & $405 b^{y}$ & $1,601 \mathrm{~b}$ & 239 a & $662 \mathrm{~b}$ & $0.027 \mathrm{~b}$ \\
\hline 0.1 単位 & 638 a & $4,371 \mathrm{a}$ & $270 \mathrm{a}$ & 1,636 a & $0.043 \mathrm{a}$ \\
\hline 0.25 単位 & $555 \mathrm{a}$ & $3,950 \mathrm{a}$ & $120 \mathrm{~b}$ & $1,478 \mathrm{a}$ & $0.048 \mathrm{a}$ \\
\hline
\end{tabular}

$\mathrm{z}(\ln$ 定植 45 日後の全新鮮重 $-\ln$ 定植当日の全新鮮重 $) \div 45$ の式で算出した

${ }^{\mathrm{y}}$ Tukey 法により同一列の異なるアルファベット間に 5\%水準で有意差あり 

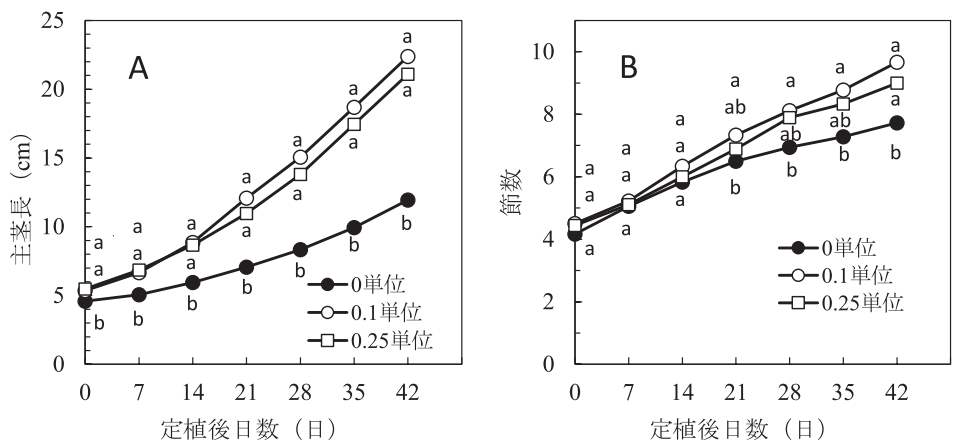

第 3 図 水挿し時の培養液濃度がウワバミソウの挿し芽苗の定植後の主茎長 (A) 拈よび節数 (B) の増加に及洔す影響 図中のアルファベットはTukey 法により同一日の異なる文字間に 5\%水準で有意差ありを示す

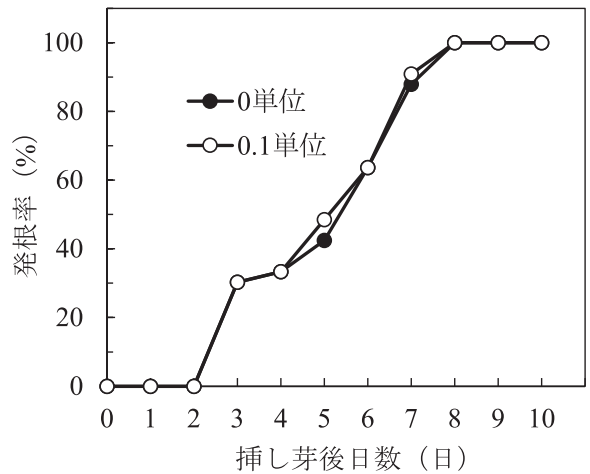

第 4 図 ウワバミソウの挿し穂の発根率に及ぼす水挿し時の 培養液濃度の影響（実験 2)

(第 5 図 C).

葉面積は, すべての調査日において 0 単位と比較して 0.1 単位で有意に広かった。 $0 / 0.1$ 単位の葉面積は, 0 単位と 比較して定植 7 日後では有意に広かったが, 定植当日お よび定植 14 日後では有意な差は認められなかった（第 5 図 D).

育苗中の RGR は， 0 単位と比較して，0/0.1 および 0.1 単位で高かった（第 2 表）。定植 $0 \sim 14$ 日後の RGR は, 0 単位と比較して, 0.1 単位では有意な差は認められなかっ たが， $0 / 0.1$ 単位では有意に低かった。 LARは，試験期 間中を通して，いずれの試験区間に特いても有意な差は認 められなかった。育苗中の NARは， $0.1 ， 0 / 0.1$ 抢よび 0 単位の順で高かった. 定植 $0 \sim 14$ 日後の NAR は, 0 単位 と比較して，0.1 単位では有意な差は認められなかったが, $0 / 0.1$ 単位では有意に低かった.

育苗中の葉に対する乾物分配率は，0 単位と比較して, $0 / 0.1$ 抢よび 0.1 単位で有意に高かった（第 3 表）。茥に 対する乾物分配率は，いずれの試験区間においても有意な 差は認められなかった。 根に対する乾物分配率は, 0 単位 と比較して，0／0.1 打よび 0.1 単位で有意に低かった。定 植 $0 \sim 14$ 日後の乾物分配率は，いずれの試験区間に打い ても有意な差は認められなかった。

\section{考察}

\section{1. ウワバミソウにおける水挿し時の培養液濃度と挿し穂} の発根および育苗中の生育の関係

実験 1 に打いて，水挿し時の培養液濃度を $0,0.1$ 打よ び 0.25 単位の 3 段階としたが，各培養液濃度での挿し穂 の発根率の推移は，ほぼ同じであった。実験 2 では培養液 濃度を 0 执よ゙ 0.1 単位として水挿ししたが，実験 1 と同 様に発根率の推移はほぼ同じであった。従って, 本研究の 範囲内では水挿し時の培養液濃度はウワバミソウの挿し穂 の発根に影響しないと考えられた。

挿し穂からの発根期間は，実験 1 では挿し芽 7〜9 日後 の間，実験 2 では挿し芽 $3 \sim 8$ 日後と異なった。この要因 の一つとして実験 1 扣よび 2 では挿し穗の採取条件が異な ることが一因と考えられるが，詳細は不明である.

実験 1 の定植当日調査で 0.25 単位の根の生育は，0 およ び 0.1 単位と比較して抑制されていた．大玉トマトでは人 工光型湛液育苗装置を利用して無肥料，大塚 $\mathrm{A}$ 処方培養 液 0.1 および 0.5 単位の培養液に挿し穂を挿して培養液濃 度と根の生育の関係を調べたところ, 無肥料と比較して 0.5 単位では根の伸長抑制や挿し穂の腐敗が認められた（岩腰 ら，2003）。レンギョウでは当年枝を挿し穂に用いてロッ クウールキューブに挿し，水道水，大塚 $\mathrm{A}$ 処方 0.1 および 1 単位培養液を 1 日に 1 回与えて培養液濃度と根の生育の 関係を調べたところ，挿し穂から発根した根の生育は水道 水と比較して 1 単位培養液では阻害された（畑ら，2009）. このように閾值は異なるが，培養液濃度が高まると挿し穂 から発根した根の生育は阻害されることが報告されてい る. 従って, 実験 1 の 0.25 単位培養液による根の生育抑 制は，培養液濃度が高いことが原因と考えられた。

大玉トマト（岩腰ら，2003）拈よびレンギョウ（畑ら, 2009）では 0.1 単位培養液で育苗中の根の生育が優れたと 報告されているが，実験 1 および 2 のいずれに拈いても定 植当日調査で 0 単位と 0.1 単位の間で根の生育差はなかっ た．従って，本研究の育苗に関する試験の範囲では，低濃 度培養液がウワバミソウの根の生育を促進する効果につい 

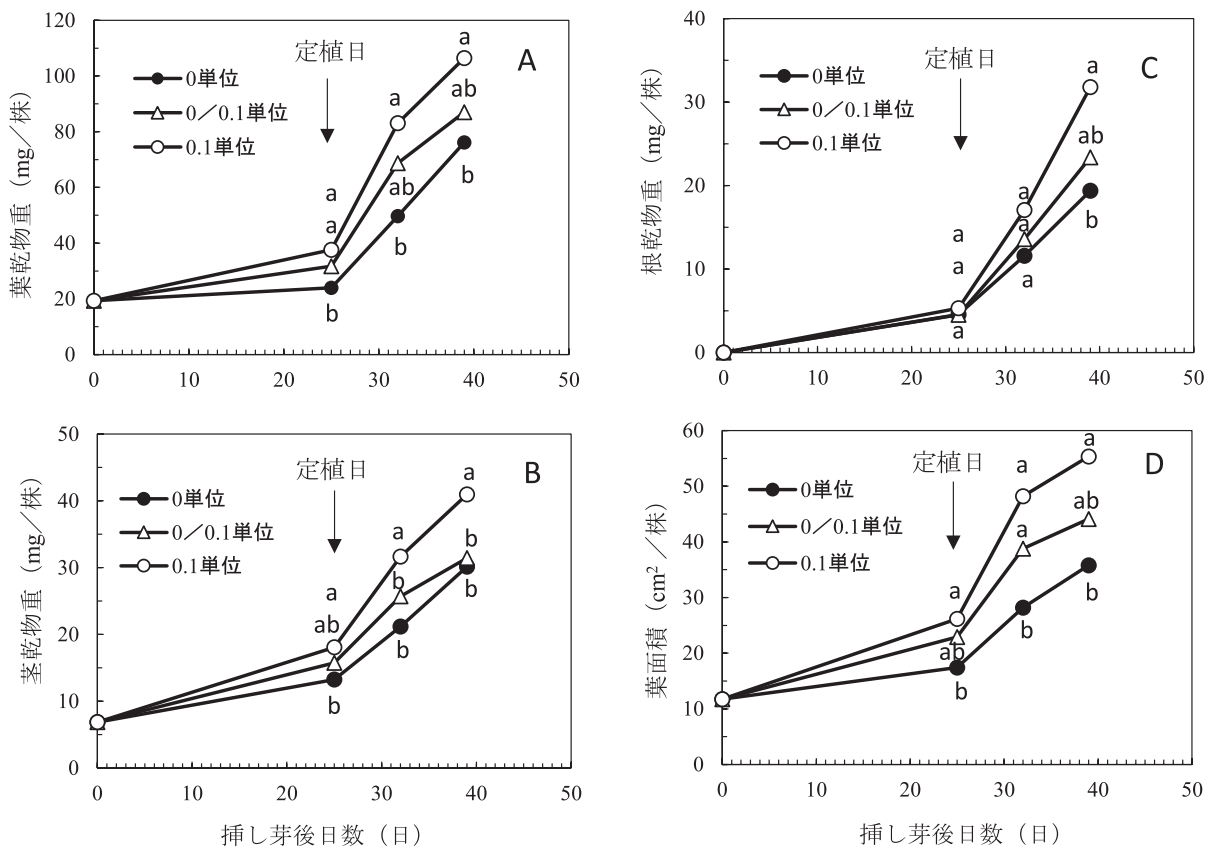

第 5 図 水挿し時の培養液濃度がウワバミソウの挿し芽苗の定植後の葉乾物重 $(\mathrm{A})$, 茎乾物重 $(\mathrm{B})$, 根乾物重 $(\mathrm{C})$ 牧よび葉面積 (D) の増加に及汴す影響

図中のアルファベットは Tukey 法により同一日の異なる文字間に 5\%水準で有意差ありを示す

第 2 表 水挿し時の培養液濃度がウワバミソウの挿し芽苗の RGR，LAR およびNAR そ及活す影響

\begin{tabular}{|c|c|c|c|c|c|c|}
\hline \multirow{2}{*}{ 培養液濃度 } & \multicolumn{2}{|c|}{$\mathrm{RGR}^{\mathrm{z}}\left(\right.$ day $\left.^{-1}\right)$} & \multicolumn{2}{|c|}{$\operatorname{LAR}^{\mathrm{y}}\left(\mathrm{cm}^{2} \cdot \mathrm{mg}^{-1}\right)$} & \multicolumn{2}{|c|}{$\mathrm{NAR}^{\mathrm{x}}\left(\mathrm{mg} \cdot \mathrm{cm}^{-2} \cdot \mathrm{day}^{-1}\right)$} \\
\hline & 育苗中 & 定植 0-14 日後 & 育苗中 & 定植 0-14 日後 & 育苗中 & 定植 0-14 日後 \\
\hline 0 単位 & $0.019 b^{w}$ & $0.079 \mathrm{a}$ & $0.436 \mathrm{a}$ & $0.337 \mathrm{a}$ & $0.044 \mathrm{c}$ & $0.235 \mathrm{a}$ \\
\hline $0 / 0.1$ 単位 & $0.028 \mathrm{a}$ & $0.070 \mathrm{~b}$ & $0.446 \mathrm{a}$ & $0.362 \mathrm{a}$ & $0.063 \mathrm{~b}$ & $0.196 \mathrm{~b}$ \\
\hline 0.1 単位 & $0.034 \mathrm{a}$ & $0.077 \mathrm{ab}$ & $0.440 \mathrm{a}$ & $0.353 \mathrm{a}$ & $0.079 \mathrm{a}$ & $0.221 \mathrm{ab}$ \\
\hline
\end{tabular}

z, y, x RGR は相対成長率，LAR は葉面積比，NAR は純同化率を示す

${ }^{\mathrm{w}}$ Tukey 法により同一列の異なるアルファベット間に 5\%水準で有意差あり

第 3 表 水捙し時の培養液濃度がウワバミソウの挿し芽苗の乾物分配率に及ぼす影響

\begin{tabular}{|c|c|c|c|c|c|c|}
\hline \multirow{3}{*}{ 培養液濃度 } & \multicolumn{6}{|c|}{ 乾物分配率 z （\%) } \\
\hline & \multicolumn{3}{|c|}{ 育苗中 } & \multicolumn{3}{|c|}{ 定植 0-14 日後 } \\
\hline & 葉 & 茎 & 根 & 葉 & 茎 & 根 \\
\hline 0 単位 & $26.6 \mathrm{~b}^{\mathrm{y}}$ & $42.8 \mathrm{a}$ & $30.5 \mathrm{a}$ & $62.2 \mathrm{a}$ & $20.2 \mathrm{a}$ & $17.6 \mathrm{a}$ \\
\hline $0 / 0.1$ 単位 & $48.1 \mathrm{a}$ & $34.4 \mathrm{a}$ & $17.5 \mathrm{~b}$ & $60.7 \mathrm{a}$ & $19.3 \mathrm{a}$ & $20.0 \mathrm{a}$ \\
\hline 0.1 単位 & $53.4 \mathrm{a}$ & $31.8 \mathrm{a}$ & $14.8 \mathrm{~b}$ & $57.8 \mathrm{a}$ & $20.3 \mathrm{a}$ & $21.9 \mathrm{a}$ \\
\hline
\end{tabular}

$\mathrm{z}$ 育苗中あるいは定植 0-14 日後の各器官の乾物増加量 $\div$ 全乾物増加量 $\times 100$ で算出した

${ }^{\mathrm{y}}$ Tukey 法により同一列の異なるアルファベット間に 5\%水準で有意差あり

ては確認できなかった。

実験 1 および実験 2 に打いて，育苗終了時の地上部の生 育は培養液濃度を高めると促進され，根の生育と異なる傾 向を示した．実験 2 の育苗中の成長解析の結果では, $0 / 0.1$ および 0.1 単位の RGR は, 0 単位と比較して高い数值を 示し，その要因はNARの上昇によるものであった，光合 成速度は施肥により高まることから，0.1 括よび 0.25 単位
培養液を用いることで，0 単位と比較して挿し穂の光合成 速度が高まったと推測される。また，加藤・鐘（1987）は， トマト，ナス拈よびピーマンの実生苗を用いて培養液濃度 を $1 / 2 ， 1 ， 2$ 扎よび 4 倍として砂耕した結果，培養液濃 度が高まるにつれて葉への乾物分配が上昇し，根への分配 は低下したと報告した。池ら（1991）は，トマトの実生苗 を用いて培養液濃度を $1 / 4,1 ， 2 ， 4$ 扎よび 8 倍として水 
耕した結果, 培養液濃度が増加するほど地下部への乾物分 配率は低下し, 地上部への乾物分配率は上昇したと報告し た. 実験 2 の育苗中の地上部（葉と茎の合計）への乾物分 配率は，0 単位では約 71\%であったのに対して，0０.1 単 位では約 $83 \% ， 0.1$ 単位では約 $85 \%$ と高く，特に $0 / 0.1$ 扣よび 0.1 単位では 0 単位と比較して葉への乾物分配率が 上昇し，根への乾物分配率が低下寸る傾向であった。この ように，植物種や栽培条件が異なるが，培養液濃度と乾物 分配率の関係は, ナス科野菜の実生苗と同じ傾向を示した. 以上のことから，培養液濃度を高めることで地上部の生育 が優れた要因は, 地上部に対する乾物分配率の上昇执よび NARの上昇を根拠とした RGR の増加によるものであると 考えられた.

実験 2 に扮いて，0.1 単位では挿し芽当日から 0.1 単位 培養液を用いたのに対して，0０.1 単位では挿し穂が発根 した後である挿し芽 14 日後に培養液濃度を 0 単位から 0.1 単位に変更して管理した. 定植当日調査では, 0.1 単位の 地上部の生育は, $0 / 0.1$ 単位と比較して有意な差は認めら れないが優れる傾向であり, 育苗中の RGR も約 $26 \%$ 高かっ た. 従って, 地上部の生育を促進させるためには挿し芽当 日から 0.1 単位培養液を与えると良いと考えられた。

\section{2. ウワバミソウにおける水挿し時の培養液濃度と定植後 の生育の関係}

実験 1 に打いて, 0.1 単位と 0.25 単位の定植後の生育の 推移は，ほ接同等であり，0 単位と比較して優れたことか ら, 肥料を多く必要とする 0.25 単位の培養液で插し芽苗 を育成する利点は認められなかった。 また，実験 2 に打い て, 0.1 単位の生育は, 0 および $0 / 0.1$ 単位と同等であった. 従って，育苗中だけでなく定植後の生育の点からも，挿し 芽苗の生育を促進させるためには插し芽当日から 0.1 単位 培養液を与える方が良いと考えられた.

実験 2 において，定植 $0 \sim 14$ 日後の $0 / 0.1$ 単位の RGR は, 0 単位と比較して大幅に低下し, その要因はNARの 低下によるものであった. 有意な差は認められないものの, 定植 14 日後の $0 / 0.1$ 単位の根乾物重は 0 単位と比較して 重く, $0 / 0.1$ 単位の根に対する乾物分配率は 0 単位と比較 して高くなる傾向であったことから，RGRが低下した要 因の一つとして，根量の増大に伴ら呼吸量の増加により NARの低下が起こったものと推測される。しかしながら， 0.1 単位の RGR およびNAR は 0 単位と同等であったこと から, 要因解明のために詳細な研究が必要である.

以上のことから, 本研究の範囲内では, 0.1 単位培養液 に水挿しすることで育苗中括よび定植後の挿し芽苗の生育 を促進できると考えられた。

\section{摘 要}

ウワバミソウを用いて, 水挿し時の培養液濃度と挿し穂 の発根および生育の関係を調査した. 插し穂の発根率の推 移は, 水挿し時に $0.1 \sim 0.25$ 単位の培養液を用いても 0 単
位と比較して同等であった. 0.1 単位の培養液で水扦しし て育成した挿し芽苗は，0 単位と比較して，定植時の地上 部が大きく, 定植後の生育も優れた。 0.25 単位の培養液に 水扦しして育成した挿し芽苗は, 定植時の根量が減少した. 成長解析の結果， 0.1 単位の培養液に水抻しした挿し芽苗 の育苗中の相対成長率は，0 単位と比較して高かった。相 対成長率の違いはほぼ純同化率の違いに連動していた。

\section{引用文献}

池 性韓・篠原 温・鈴木芳夫. 1991. 種々の培養液濃度 および通気時間が水耕トマト苗の乾物生産和よび分配 に及ぼす影響. 生物環境調節. 29: 27-33.

畑 直樹 - 岡澤敦司・森本絹世 - 小埜栄一郎・佐竹 炎 ・ 小林昭雄. 2009. レンギョウ緑枝挿しの発根に及ぼす IBA 浸漬処理, 液肥施用, 日長拈よび光強度の影響. 植物環境工学. 21: 15-23.

岩腰芳人・嶋田奥左エ門・三谷和弘. 2003. トマト苗大量 生産のための人工光型湛液挿し芽育苗法. p. 41-42. 福井県農林水産部編. 普及に移した技術平成 11 年度〜 平成 15 年度. 福井県農林水産部. 福井.

加藤 徹・鐘 鈴鋒. 1987. ナス科果菜の比較生理生態的 研究 (第 1 報) 培養液濃度が生長, 久かけの同化量, 葉の蒸散作用扣よび根の呼吸に及ぼす影響. 生物環境 調節. 25: 7-12.

劉建・辺 嘉賓 - 塩津文隆・Subhash Chandra Ghosh • 豊田正範・楠谷彰人. 2008. 水耕栽培で塩ストレスを 与えた水稲品種の耐塩性と根系形態. 日作紀. 77: 326-332.

牧野富太郎. 1940. 牧野日本植物図鑑. p. 643. 北隆館. 東京.

水島智史. $2015 \mathrm{a}$. 珠芽由来のウワバミソウの生育に及ぼ す培養液濃度の影響. 植物環境工学. 27: 75-81.

水島智史. 2015b. ウワバミソウの挿し芽苗の生育に及ぼ す培養土の窒素施肥量および水耕時の培養液濃度の影 響. 園学研. 14: 135-139.

並木隆和・小田雅行・工藤康将・高嶋四郎. 1977. 蔬菜水 耕栽培の実用化に関する研究 XVIトマトの断根さし 木育苗. 京都府大学報 (農). 29: 17-22.

西尾譲一・山内高弘・原 幹博. 1994. キクのセル成型育 苗に扣ける好適な培地条件について. 愛知農総試研報. 26: $233-240$.

大沢 章. 1986. 山菜栽培全科一有望 53 種一. p. 64-73. 農文協. 東京.

白井建史・萩森 学. 2004. ピーマン (Capsicum annuum L.) の大量増殖法. 園学雑. 73: 259-265.

谷川孝弘・國武利浩・中村知佐子・山田明日香・巣山拓郎・ 佐伯一直. 2010. 夏秋ギクの親株養成に打ける栽培条 件の違いが挿し穂収量と苗質に及ぼす影響. 園学研. 9: 31-38. 